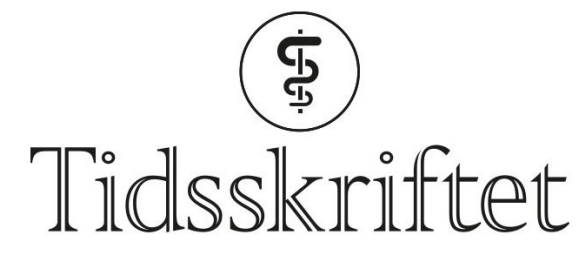

DEN NORSKE LEGEFORENING

\title{
Kjærlighet trenger et språk
}

INTERVJU

ANNE KATHRINE SEBJØRNSEN

E-post:annekaths@hotmail.com

Hege Saltnes var 24 år, legestudent og gravid med sitt første barn da ektemannen plutselig ble helt døv. Hva skjer når man ikke lenger har et felles språk?

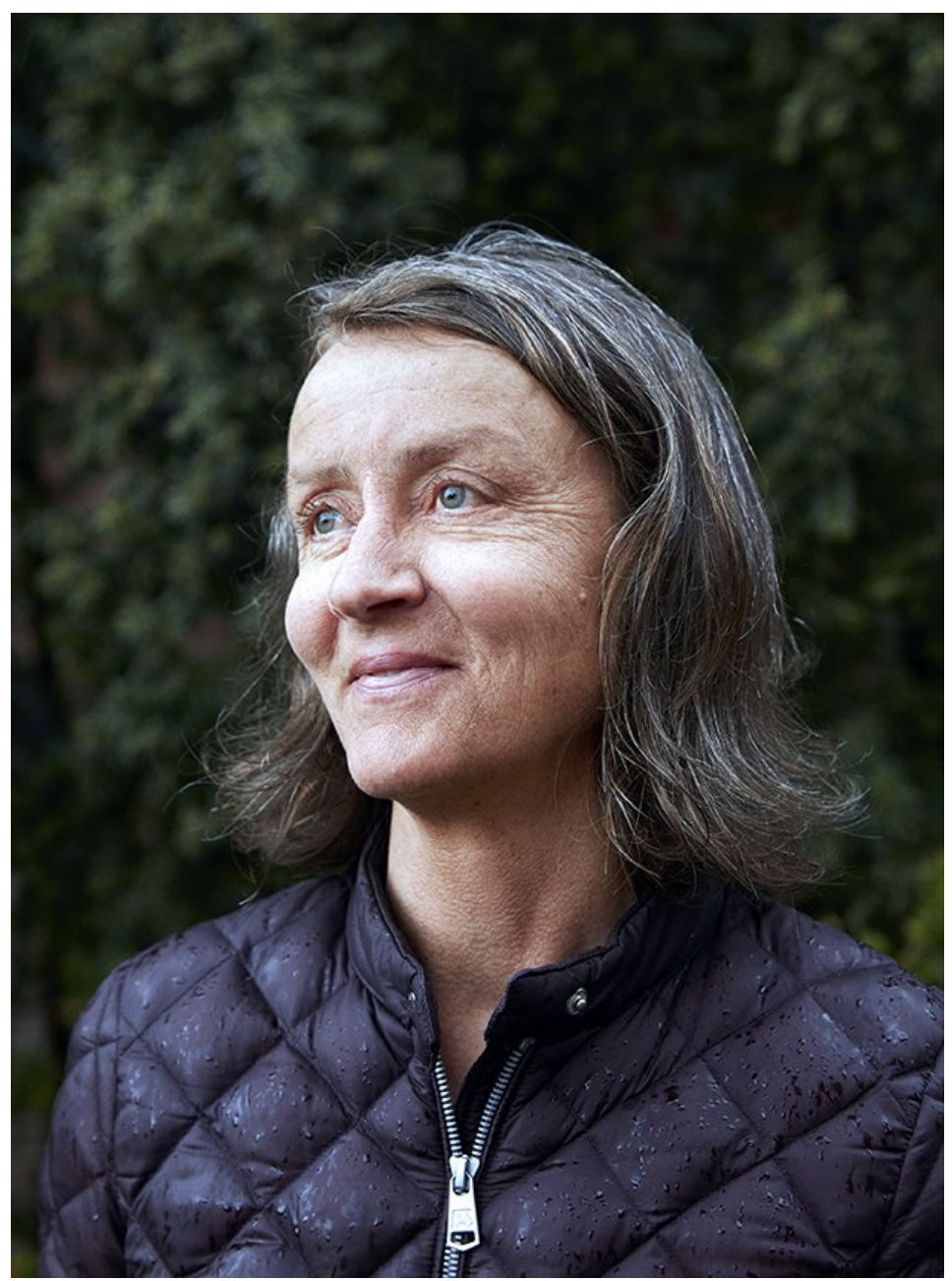

Foto: Birgit Solhaug

Hege var 19 år og hadde nettopp kommet inn på medisinstudiet i Bergen da hun møtte igjen den seks år eldre Knut Rune på Frikirkens galleri i hjembyen Risør. Han hadde spilt en viktig rolle for henne i en vanskelig situasjon mange år tilbake, og nå sto han der igjen. Høyere, mørkere og kjekkere enn hun husket. Siden sist hadde han studert kristendom og 
gjennomgått en meningokokkmeningitt som førte til bilateral hørselsnedsettelse og store balanseproblemer. Nå var han i gang med å trene seg opp igjen.

Hege ble akutt og inderlig forelsket, og de giftet seg to år senere. Kort tid etter bryllupet fikk han plutselig hørselstap (sudden deafness) på det ene øret. Noen år senere mistet han også hørselen helt på det andre.

- Mannen min skjønte plutselig ikke hva jeg sa lenger. Jeg var 24 år, gravid og legestudent på nest siste året. Vi gikk på tegnspråkkurs og i parterapi. Når jeg snakker om det nå, skjønner jeg jo at det var ekstremsport, men vi tenkte ikke sånn på det da. Det var bare noe vi måtte få til, for vi hadde jo ikke et felles språk. Småprat fungerer jo dårlig da, sier hun og smiler litt.

- Hvordan klarte dere å sette inn det ekstra giret for å lære tegnspråk midt i denne krisen?

- Det var et følelsesmessig kaos, men motivasjonen var høy, samtidig som vi ikke hadde noe valg. Hvis du får kreft, tar du jo den cellegiftkuren, liksom. Vi var kjempeglade for å skulle bli foreldre, samtidig som vi hadde en sorg over hørselstapet. I starten trodde nok Knut Rune at hørselen skulle komme tilbake. Han hadde erfart at han kunne trene opp balansen igjen, og tenkte at det var sånn med hørselen også. Tegnspråk var noe fremmedartet, men det var også fascinerende at vi kunne bruke et språk som ingen andre enn vi forsto. For min del var det nok et beskytterinstinkt som slo inn. Vi skulle verne om den lille flokken vår, sier hun ettertenksomt.

Noen ganger er det en fordel å være litt naiv, for da tenker man at ting kommer til å løse seg

Hege Saltnes, som nå er seksjonsleder ved Nasjonal behandlingstjeneste for hørsel og psykisk helse, tenker seg om, lener seg tilbake, er tydelig berørt. Hun forteller at hun og Knut Rune snakket sammen i går for å forberede dette intervjuet, og at det var lenge siden de hadde satt seg ned og reflektert over historien sin.

- Noen ganger er det en fordel å være litt naiv, for da tenker man at ting kommer til å løse seg. Og så hjalp det at jeg var så ekstremt forelska, sier hun og ler hjertelig.

- Du har sett han, eller? Han er jo en kjekk mann, da! Høy og mørk, eller ... jeg trodde i hvert fall det. Da han var hos fastlegen sist, viste det seg at han er fire centimeter lavere enn jeg alltid har trodd. Hege humrer.

- Men nå er du flytende i tegnspråk?

- Etter 32 år som tegnspråkbruker kommuniserer jeg fortsatt ikke perfekt. Det er et tredjespråk, og jeg blir aldri like flytende som de som har lært det fra tidlig alder. Jeg synes døtrene våre er gode eksempler på det. Da vi fikk vår første datter, Frøydis, var vi uerfarne tegnspråkbrukere og hadde ikke nok kompetanse til å lære henne det i tidlig alder. Vår andre datter, Runa, kunne gi uttrykk for sine behov med tegn da hun bare var ti måneder gammel. Nå tar hun en mastergrad i psykologi og omsetter en språktest til norsk tegnspråk, forteller hun.

\section{Verdien av egne erfaringer}

Historien til Hege og Knut Rune Saltnes er unektelig en vakker kjærlighetshistorie, men det er også en historie om å akseptere livet som det er og finne løsninger på praktiske utfordringer. Knut Rune var helt døv i mange år, før han fikk operert inn cochleaimplantat og fikk noe hørsel tilbake. Hjemmespråket har gått fra å være tegnspråk i mange år til nå primært å være lydbasert, med tegnstøtte ved behov. Kommunikasjonen går imidlertid ikke knirkefritt.

\section{Hege Saltnes}

Født 1964

Cand.med., Universitetet i Bergen/Trondheim 1991 
Lege, Andebu kompetanse- og skolesenter/Andebu 1993-95

Lege i spesialisering i psykiatri/konstituert overlege, Sykehuset i Vestfold 1995-2001

Overlege i psykiatri, Sykehuset i Vestfold 2001-07

Styremedlem i Overlegeforeningen 2005-08

Overlege, Nasjonalt senter for hørsel og psykisk helse, Oslo universitetssykehus, 2007-14

Medlem i den rettsmedisinske kommisjon, psykiatrisk gruppe 2009-15

Master i erfaringsbasert helseadministrasjon 2018-20

Seksjonsleder og overlege, Nasjonal behandlingstjeneste for hørsel og psykisk helse

2014-d.d.

- En bivirkning av å være tunghørt er at du tror du har hørt og forstått. Du setter sammen brokker av det du hører og gjetter på meningsinnholdet. Vi opplever mange situasjoner der vi tror vi har gjort en avtale, mens det viser seg at vi snakker om helt forskjellige ting. En jul hadde han ikke fått med seg at vi skulle feire hos søsteren min i Oslo og forsto ingenting da vi pakket koffertene.

Tegnspråk er et tredjespråk, og jeg blir aldri like flytende som de som har lært det fra tidlig alder

- Han hadde ikke spurt om juleferien?

- Man spør jo ikke om det man ikke har hørt. Sånne situasjoner oppstår også på jobben.

Plutselige endringer i avtaler oppfatter han ofte ikke. De tingene det snakkes om i gangen, men som ikke står i møtereferater, kan det være sårt å ikke få med seg. Som at folk er alvorlig syke, det skrives jo ikke i referatene. Knut Rune kan plutselig få en opplevelse av at det er noe han ikke vet. Vi med god hørsel tror at de med dårlig hørsel vet det samme som oss, men det gjør de ikke alltid, understreker hun.

\section{Det sosiale tapet}

Historien er imidlertid godt bearbeidet og situasjonen vel akseptert av dem begge. Det sosiale livet har likevel blitt litt annerledes enn de hadde ønsket. 


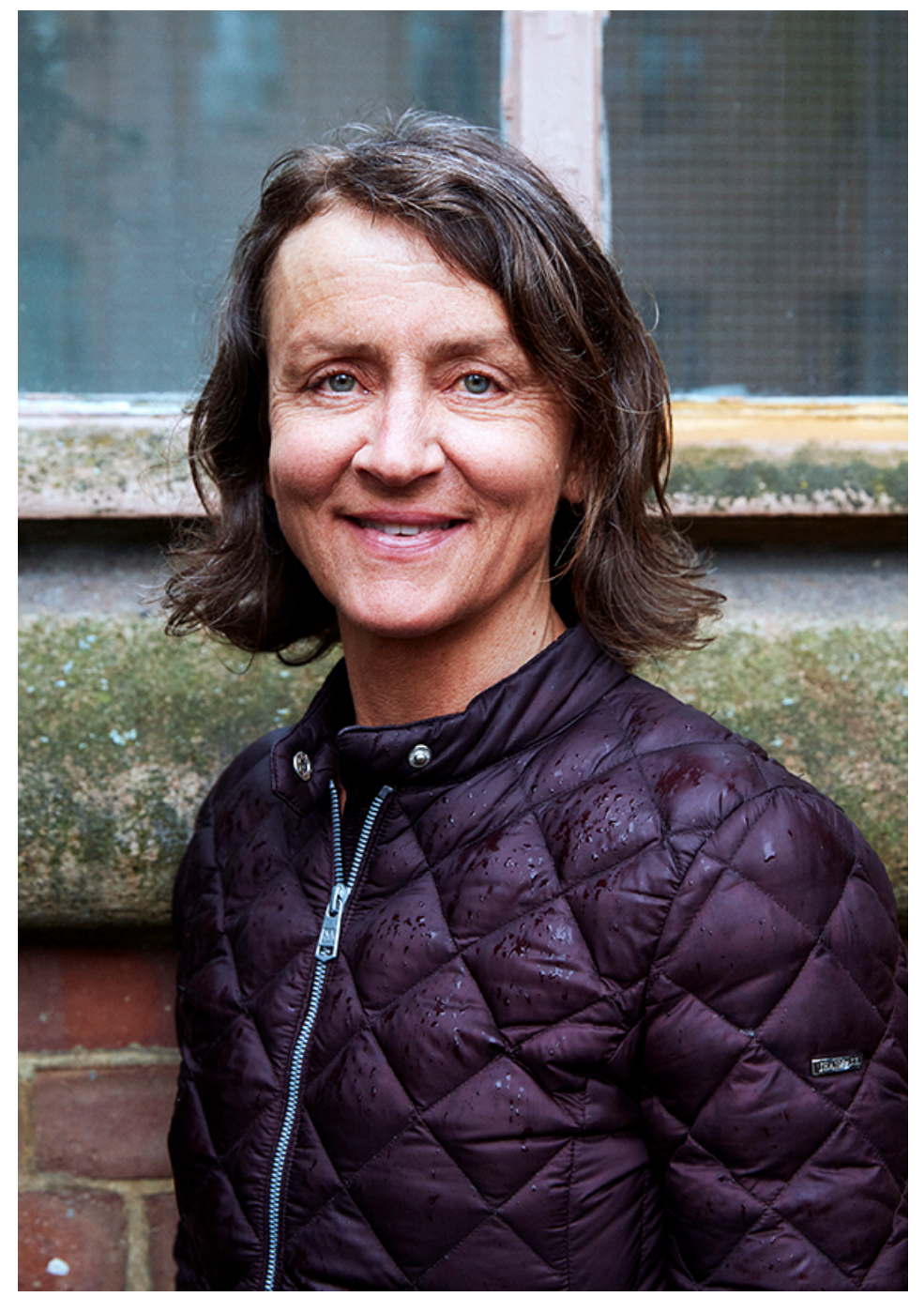

Foto: Birgit Solhaug

- Den største sorgen for meg, som er en veldig sosial person, er at vi ikke kan ha mange på besøk samtidig. Vi har måttet lage en slags sosial liste der vi ber maks to av gangen for at det skal være mulig for Knut Rune å følge med i samtalen. Vi har nok en felles sorg i forhold til det sosiale. Da barna var små, var det ofte han ikke fikk med seg hva de sa. Det samme skjer med barnebarna nå, men sånn er det bare, slår hun fast.

Hege Saltnes har alltid vært mer opptatt av hva hun får til enn hva hun ikke får til. Det tror hun har vært en styrke inn i deres felles prosjekt.

- Samtidig er ikke Knut Rune en som har sutret over livssituasjonen sin. Hans historie er nok annerledes enn min, mer aksepterende. Hørselstapet har faktisk bidratt til at han har fått utrolig spennende jobbmuligheter. Han har jobbet verden rundt med bistandsprosjekter for Stiftelsen Signo, blant annet i Kina for å bygge opp tegnspråkundervisning til døve barn, og med døve i Palestina, sier hun, og legger til at Knut Rune har påpekt at hun ikke liker syting.

- Situasjonen dere havnet i har faktisk gitt dere begge spennende karrieremuligheter?

- Absolutt. Erfaringskompetansen har dessuten vært gull verdt i jobbsammenheng for både han og meg. Når jeg foreleser om hørselstap og psykisk helse, er jeg ikke bare en ekspert som står der og «kakler». Jeg bruker min egen historie, om hvordan jeg tar meg selv i å stå og rope til den døve mannen fra tredje etasje. Det gir meg en annen posisjon enn om jeg bare hadde vært en fagperson, understreker hun.

\section{Gleden ved å se andre mestre}

Hege Saltnes går oftest med kjappe, målrettede skritt gjennom gangene i det fredede tårnbygget på Gaustad hvor Nasjonal behandlingstjeneste for hørsel og psykisk helse er 
lokalisert. Ikke bare fordi hverdagen er hektisk, men også fordi hun har mye energi hun må få utløp for - såpass mye at hun ofte synes det er nødvendig å gå hjem fra jobb, for så å trekke bildekk etter seg på skogsveiene i Nordmarka, trene til neste maraton eller til Birken. Ikke helt sjelden dreier praten rundt lunsjbordet seg om hvilken ekspedisjon Hege la ut på i helgen, eller hvor i marka det er bra å trekke bildekk. Drivkraften for å få til det umulige har vært god å ha når utfordringene har vært store.

Når jeg foreleser om hørselstap og psykisk helse, er jeg ikke bare en ekspert som står der og 'kakler'

- Jeg liker å ha prosjekter og å teste egne fysiske grenser, liker å jobbe for å nå et mål. Men det som virkelig rører og gleder meg, er å se andre klare noe de ikke trodde de skulle få til, sier hun og viser frem et bilde fra da hun syklet Lillehammer - Oslo på tandemsykkel sammen med sterkt synshemmede Eline noen år tilbake. Engasjementet for mennesker med sansetap har blitt en livsstil. På fritiden er hun frivillig ledsager for synshemmede.

- Å være ledsager er et bidrag til at andre også kan nå målene sine. Det gir meg masse glede, og det er fascinerende å se at det faktisk går an. Gleden ved å ledsage en synshemmet på Birkebeinerrennet er mye større enn å løpe New York City Marathon for egen del. Jeg blir generelt veldig berørt i situasjoner der noen når målene sine og får til noe de ikke trodde de skulle klare.

- Du bruker fysisk mestring som virkemiddel i møte med pasienter også?

- Absolutt! En av mine døvblinde pasienter med betydelig helseangst trodde han skulle d $\varnothing$ hvis han fikk puls over 110. Vi jobbet med kognitiv atferdsterapi og eksponering, inntil han løp sentrumsløpet med meg som ledsager som avslutning på terapien. Man kan jo ikke ha en bedre jobb enn det? Hun smiler fornøyd.

\section{Å være menneske med sansetap}

Den opprinnelige planen hennes var å bli kardiolog. Tilfeldighetene ville ha det til at hennes første jobb på Sykehuset i Vestfold var på psykiatrisk avdeling, ikke indremedisinsk.

- Jeg syntes det var helt nydelig å jobbe i psykiatrien og tok hele spesialiteten ved Sykehuset i Vestfold. Etter hvert kjente jeg på at rammevilkårene for akuttpsykiatri ikke var gode, og jeg begynte å lengte ut. Det var en tilbakevendende tanke at det å jobbe med døve med psykiske lidelser kanskje var «min ting». Da jeg ble forespurt om å begynne å jobbe som psykiater på Døveavsnittet på Gaustad, måtte jeg gripe muligheten, forteller hun. 


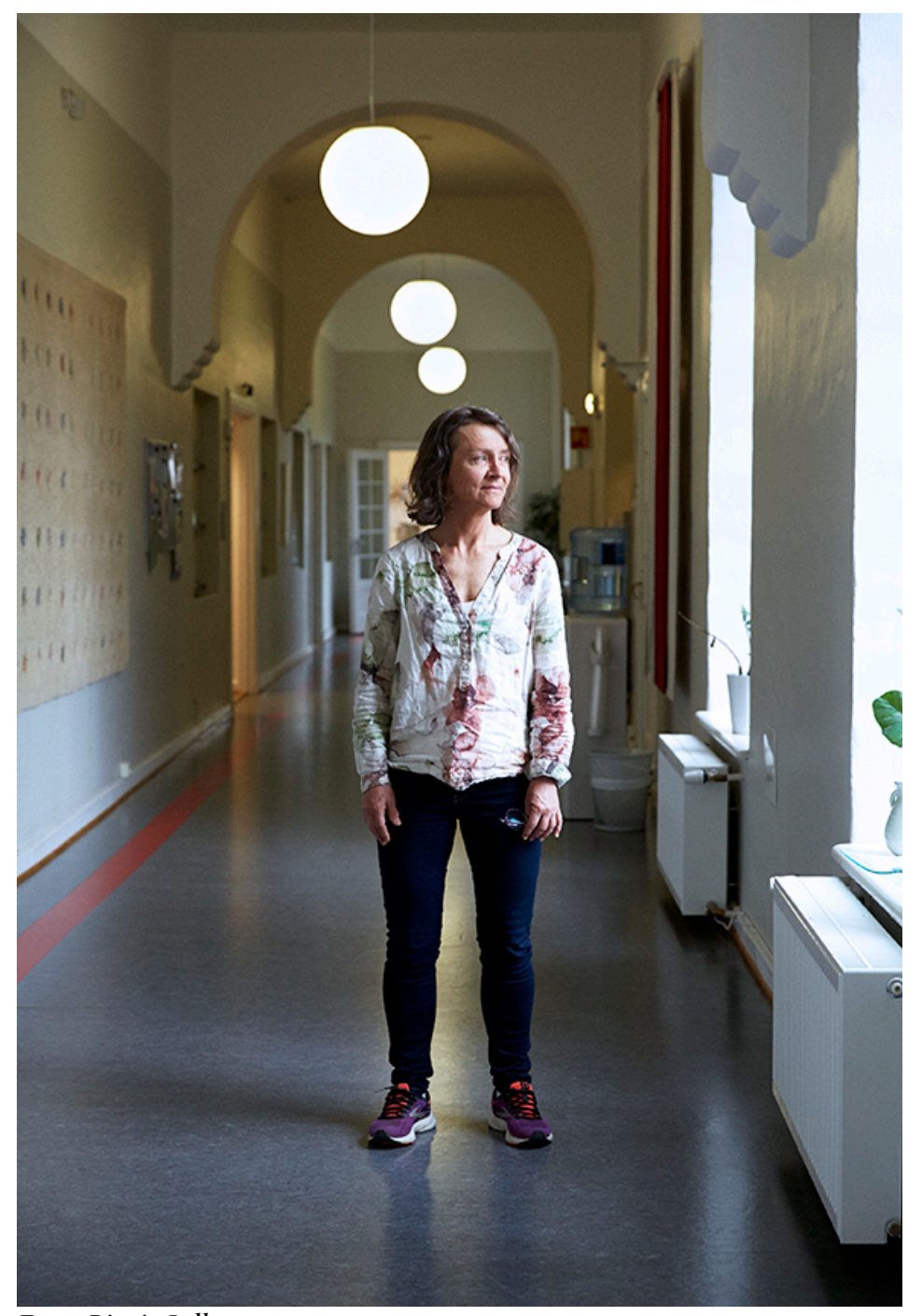

Foto: Birgit Solhaug

Senere ble hun leder og fikk være med på etableringen av en nasjonal behandlingstjeneste for hørsel og psykisk helse. Nå er en utvidelse av behandlingstjenesten på trappene. Fra 1. mai i år tar de også imot synshemmede med psykisk lidelse. Drømmen er at alle personer med sansetap kan få et tilbud på sikt.

Å være ledsager er et bidrag til at andre også kan nå målene sine

Hun forteller at mange synshemmede og hørselshemmede opplever det som belastende at problemstillingene de sliter med ikke er tilstrekkelig kjent i helsevesenet. Egentlig burde alle leger sette seg ned i noen minutter og forsøke å forestille seg hvordan det ville være å miste en av sansene, mener Hege Saltnes. Hun er opptatt av at stressbelastningen ved å ha et sansetap er underkjent og at mange leger vet for lite om hvordan et sansetap virker inn på mennesker.

- Det oppleves for mange som en byrde å måtte lære opp hjelpeapparatet. Selvfølgelig oppleves belastningen ved et sansetap ulikt, men noen problemstillinger er universelle, understreker hun.

- Hvilke er det?

- Et sansetap har stor innvirkning på hvordan man fungerer som menneske i verden. Det er energikrevende, rett og slett. Hørselshemmede og blinde bruker mye mer energi, fordi de hele tiden må være på alerten for å fange opp farer som vi andre varsles om og korrigerer ut ifra. Synshemmede traumatiseres av hverdagshendelser som å ta på varme kokeplater, tråkke ned i hull i veien eller å bli påkjørt av el-sparkesykler. Hørselshemmede sover ofte dårligere alene fordi de er redde for ikke å få med seg at brannalarmen går om natten. Knut Rune sover mye dårligere uten meg, eksemplifiserer hun. 
- Og du sover dårligere uten han?

- Absolutt ikke! Jeg hører altfor godt. Jeg må faktisk bruke ørepropper for å sovne ved siden av han, svarer hun.

Publisert: 7. juni 2021. Tidsskr Nor Legeforen. DOI: 10.4045/tidsskr.21.0369

(C) Tidsskrift for Den norske legeforening 2020. Lastet ned fra tidsskriftet.no 